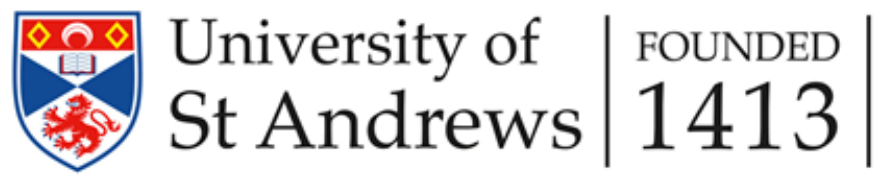

University

Library

\section{The imitation game: becoming imitators of Christ}

\author{
Cockayne, Joshua
}

\begin{tabular}{|l|l|}
\hline Date of deposit & $12 / 03 / 2018$ \\
\hline Document version & Author's accepted manuscript \\
\hline Access rights & $\begin{array}{l}\text { C Cambridge University Press 2016. This work is made available } \\
\text { online in accordance with the publisher's policies. This is the } \\
\text { author created, accepted version manuscript following peer } \\
\text { review and may differ slightly from the final published version. }\end{array}$ \\
\hline $\begin{array}{l}\text { Citation for } \\
\text { published version }\end{array}$ & $\begin{array}{l}\text { Cockayne, J. (2017). The imitation game: becoming imitators of } \\
\text { Christ. Religious Studies, 53(1), 3-24. }\end{array}$ \\
\hline $\begin{array}{l}\text { Link to published } \\
\text { version }\end{array}$ & https://dx.doi.org/10.1017/S0034412516000196 \\
\hline
\end{tabular}

Full metadata for this item is available in St Andrews Research

Repository at: https://research-repository.st-andrews.ac.uk/

\section{St Andrews Research Repository}




\section{The Imitation Game: Becoming imitators of Christ}

\section{Introduction}

The idea that imitating Christ is somehow essential for the Christian spiritual life has played an important role in the history of Christian theology. ${ }^{1}$ Søren Kierkegaard, for instance, claimed that '[o]nly the imitator is the true Christian' $(1848 / 1991,256)$ and Thomas à Kempis's The Imitation of Christ is reportedly the most read devotional work after the Bible. 2 'The disciple of Christ', we are told by an anonymous Eleventh Century theologian, 'can do nothing better than walk as Christ walked...If Christ at various times performed all these things, the disciple of Christ should also do the same' (Constable (1995), 180). Imitating Christ, it has been argued, gives us a framework for Christian moral thinking and behaviour. ${ }^{3}$ The principle behind this framework is straightforward - Christ is a morally perfect person, and if we act more like him, we will improve, morally speaking. Or, according to the popular Christian wristband, we simply need to ask: 'What would Jesus do?' every time we consider acting in a certain way, and our behaviour will become more like his.

As well as this important moral dimension to imitating Christ, there is also a theological significance to imitation. And although, as Giles Constable tells us, 'scholars have long debated over the exact meaning of "to follow" and "to imitate" in the Bible' (1995, 145), there have been some common themes which have emerged throughout the history of Christian theology. More specifically, and something which I go on to discuss in more detail shortly, it has often been argued that the imitation of Christ has an important role to play in the ordo saltutis, in particular, in our sanctification and eventual deification, when, we are told, that 'we will be like him, for we will see him as he is' (1 John 3:2; all quotations from the Bible taken from the NRSV).

However, despite there being a vast literature on the theology of imitating Christ, as well as some practical advice about how do to this, what is lacking from this literature, and what I aim to provide in this article, is an account of just what the imitation of Christ consists of and what precisely the conditions are for imitating Christ.

I begin by situating the discussion of imitating Christ in wider Christian theology, and argue that imitating Christ is an important way of engaging in the restoration of the imago dei. Using Eleonore Stump's (2010) analysis of the ordo saltutis, I discuss the importance of sanctification and imitation for the process of becoming more like Christ. This process begins, according to Stump, with the agent's justification, in which she receives the secondorder desire for union with God. The process of sanctification is the integration and reordering of the agent's desires in accord with her second-order desire for union with God. Through the process of sanctification, not only does the agent's behaviour change to become more Christ, but also she undergoes a metaphysical change too-when the process of sanctification is complete (after her death), she will be made like Christ through the process of deification. This process is a radically transformative process which re-orientates and

\footnotetext{
${ }^{1}$ See Constable, Three Studies in Medieval Religious and Social Thought, 143-218, for a detailed history of the imitation of Christ.

${ }^{2}$ According to the New Advent Catholic Encyclopaedia, the Imitation of Christ is the most read devotional work after the Bible. See, 'Imitation of Christ' in New Advent Catholic Encyclopaedia, (New York: Robert Appleton Company) Retrieved July 1, 2015 from: http://www.newadvent.org/cathen/07674c.htm

${ }^{3}$ See, for example, Bernard of Clairvaux, Sancti Bernardi opera, and Johannes Tauler, The Following of Christ.
} 
replaces the desires and preferences of the believer to bring about union with God. It is the completion of this process, or so I argue, which the imitation of Christ must aim at.

However, this discussion of the theology of imitation generates a problem which I aim to resolve: namely, if imitating Christ is a radically transformative process, it is not obvious how to practically engage with this process. That is, the simple replication of Christ's behaviour, the act of just doing what Jesus would do, might result in a mimicry of Christ's actions, but it would not allow for the kind of radical metaphysical change of becoming more like Christ. To see this problem more clearly, and to give an account just what imitating Christ consists in, we must adopt a more detailed definition of imitation. To do this, I draw on the extensive work in philosophy of cognitive psychology which seeks to explain the role of imitation in infant development. As I go on to explain, in the psychological literature on imitation there is a distinction made between different kinds of behaviour replication: (i) emulation - a kind of intention replication often seen in non-human primates, (ii) mimicrythe reproduction of a certain action without attention to an agent's intentions, and (iii) imitation - the replication of an agent's behaviour with a particular focus on their intentions. It is this third class of behaviour replication which is used in the psychological literature to explain the social, cognitive and even moral development in infants. Furthermore, it is this third kind of behaviour replication which can best help us understand what it is to imitate Christ in a radically transformative manner, or so I argue. Yet, often when we think about the imitation of Christ, the kind of behaviour replication discussed is of the first two kinds. The problem with this, as we will see, is that replicating someone's actions is insufficient for the radical change to one's self which is required for the process of sanctification.

Despite the clarity which this discussion of imitation brings, another problem arises in that imitation, as it is understood in psychology, requires an experience in which the individual somehow perceives the intentions of the person she is imitating. However, it is not obvious that we have this kind of access to Christ, and so it is not clear that this level of contact is possible for our imitation of him. This leaves us with a dilemma-either we downplay the theological significance of imitating Christ as a transformative process, or we adopt an impossible standard for imitating Christ which is only available for the First Century disciples, and Paul the Apostle (i.e. those who come into direct contact with Christ).

A solution to this dilemma can be found, I argue, by noting that the Christian tradition emphasises that Christ is not merely a historical figure, but rather, a living person who we can somehow experience the presence of today, as Christ tells his disciples in the Gospel According to Matthew: 'I am with you always, to the end of the age' (Matthew 28:20). This discussion of presence and imitation also benefits, I argue, from considering the doctrine that not only is Christ present to and with his followers, but also, the Holy Spirit is present in his followers (Romans 8:11). According to the New Testament writers, the Holy Spirit helps us to become more Christ in some way. Following Adam Green (2009), and Eleonore Stump (2013), I claim that another discussion in cognitive psychology can help us here-both the presence of Christ and the indwelling of the Holy Spirit, according to Green and Stump, can be understood as instances of what psychologists call 'joint-attention'. That is, experiences of God's presence can be understood as experiences in which God and the believer are aware of each other and are both aware of each other's awareness of one another. This kind of attention sharing is essential for imitation, as it is discussed in cognitive and developmental psychology. And so, if this is the best way of understanding experiences of Christ and the indwelling of the Holy Spirit, then imitating Christ is still possible. The result of this is that cultivating the presence of Christ and sharing attention with him becomes crucially important 
for the task of imitating Christ. This position then gives an important role for spiritual practises which allow us to share attention with Christ in the Christian spiritual life.

\section{A theology of imitation: restoring the imago dei}

Before giving a more specific account of what imitation consists of, it will first be important to situate our understanding of imitating Christ in wider Christian theology. In seeing the development of imitation in Christian theology, we will have a better grasp of what an account of imitation needs to explain. ${ }^{4}$

Although the language of imitation, $(\mu \mu \eta \tau \eta \dot{\zeta})$ is only found in the New Testament letters, the human imitation of the divine can be traced through the whole of Christian Scripture. In the creation narrative in Genesis, human beings are described as distinct from the rest of creation in that they are made in the image of God (Genesis 1:27). This affords humanity a dominion over creation and an intimate union God and the imago dei is crucial to understanding this relationship. The distortion of the image of God is seen starkly in the fall of humanity (Genesis 3 ) in the loss of union with God. And so, the starting point of Christian Scripture is that humanity is made to reflect God but this image is distorted by sin. The image of God is never fully restored in human beings until the process of deification is complete (more on this later), through the salvific power of Christ. The process of becoming more like Christ in this life, although never complete, is what theologians describe as the process of sanctification. ${ }^{5}$

We see very early in the Torah that the command to imitate God is an essential part of the Jewish law; God commands the Israelites in Leviticus to be 'holy because I am holy' (Leviticus 11:44-45) ${ }^{6}$. This command to 'be holy because I am holy' is a command to engage in the restoration of the imago dei in human beings by acting in God's likeness. However, this is not made possible through direct contact with God; instead the commands of God are mediated and passed down through specific individuals chosen to decree God's laws and words to his people. So whilst Moses is described as communing 'face to face with God as one speaks to a friend' (Exodus 33:11), the Israelites could not even look upon the face of Moses after being in the presence of God, and the human contact with the divine was

\footnotetext{
${ }^{4}$ There will not be room to give a detailed overview of imitation in Scripture, in particular, one discussion I overlook entirely is the distinction between 'following' and 'imitating'. Christ asks for followers (Matthew 4:19) and not imitators, and it is only in Paul's writing that the language of ' $\mu \mu \eta \tau \eta \dot{s}$ ' (mimètēs) is used in his encouragement to imitate God, Christ and himself. See, 1 Corinthians 4:16, 1 Corinthians 11:1, Ephesians 5:1, 1 Thessalonians 1:6 and 1 Thessalonians 2:14. The reason I do not discuss this, is because often in the theological literature, and even in Biblical translation, following and imitating are used synonymously. For more on this difference, see Constable (1992, 145-6).

${ }^{5}$ In the history of theology there has sometimes been a distinction made between 'image' and 'likeness'. Rupert of Deutz $(1966,188)$ for instance, claimed that after the fall, human beings retained the likeness of God, in virtue of her reason and freedom of will but lost the image of God in her lack of virtue (see, Constable (1995), 167). Rupert maintained that God preordained that humanity would both fall and be restored into his likeness (Constable (1995), 167). In more recent theology this distinction between image and likeness has been blurred, but the idea that imitating Christ is restorative in bringing us closer into the image or likeness of God has remained. I do not follow Rupert's distinction here, but do think that it is important to distinguish between image and likeness.

${ }^{6}$ We see a similar command in Leviticus 19:2, Leviticus 22:28 and Jeremiah 31:33.
} 
mediated to such an extent that they could only see God's glory reflected in the veiled face of Moses (Exodus 34:34-5). This model of imitation is seen throughout the Old Testamenthumanity is always in mediated contact with God, and relates to the divine 'under the veil' of whoever the prophet, king or leader of the time is.

The imitation of Christ stands in stark contrast to the indirect, mediated account of imitation we see in the Old Testament. The imitation of Christ makes possible the full restoration of the imago dei and overcomes the superficial, mediated imitation which is possible through Moses. This contrast between the imitation made possible through Moses and the imitation possible through Christ is seen most clearly in a passage from 2 Corinthians in which St Paul writes that

[s]ince we have such a hope, we are very bold, not like Moses, who put a veil over his face so that the Israelites might not see the end of the fading splendour. But their minds were hardened; for to this day, when they read the old covenant, that same veil remains unlifted, because only through Christ is it taken away. Yes, to this day whenever Moses is read a veil lies over their minds; but when a man turns to the Lord the veil is removed. Now the Lord is the Spirit, and where the Spirit of the Lord is, there is freedom. And we all, with unveiled face, beholding the glory of the Lord, are being changed into his likeness from one degree of glory to another; for this comes from the Lord who is the Spirit. (2 Corinthians 3:12-18)

Here, Paul discusses the New Covenant between God and humanity in which the imago dei is restored through our relationship with Christ. Paul directly contrasts the mediated relationship made possible under the Old Covenant with the New Covenant in which Christ takes the veil away between humanity and God. Whereas the Israelites could access the divine presence indirectly through the veiled face of Moses, the Christian is able to approach God 'face to face' through Christ. The imitation of Christ then becomes an integral part of how we are redeemed from sin, begin the process of sanctification, and enter into union with God. The believer now has a direct access to God through Christ made possible by the presence of the Spirit.

Let us spell these themes out more explicitly. The presence of human sin means that human beings, although created to be in union with God and to reflect his likeness, cannot be in such a relationship. As Stump (2003) discusses, this can be understood in terms of two distinct problems. First, the problem of past sin: how can a just God enter into union with humans who have committed bad acts? And secondly, the problem of future sin: how can a holy God enter into union with humans who are the kind of thing that do commit bad acts $((2003,430)$ ? According to Stump, our understanding of the ordo salutis (justification, sanctification, and deification) addresses both of these problems in different ways, and helps us to see the importance of imitation for the redemption of human beings, which should be understood, for the purposes of this discussion, in terms of the restoration of the imago dei.

As Stump puts it, the result of human sin is that human beings lack the resources to come into union with God, since their desires are not aimed at union with God. The process of transformation, which seeks to redeem human beings, begins with justification, which crucially, according to Stump, begins with 'a free act of will in which a person hates his own moral wrong and longs for the goodness that is God's' $(2010,163)$. In order for this to occur Stump thinks, the agent must receive the second-order desire for union with God as a gift of grace from God $(2010,163)$. 
The second stage in this process of transformation is sanctification. Sanctification of human beings requires an engagement in the process of becoming more Christ like through the re-orientation and integration of our desires in accord with the second-order desire for union with God. As Stump writes, sanctification is the 'process in which God cooperates with a human person's higher-order desires' a process which will 'eventually culminate in a state of complete moral goodness' $(2010,160)$. Sanctification is the process of God helping an agent to integrate her second-order desire for union with God with her first order-desires. As Stump notes, however, 'the process of sanctification is not finished during a person's lifetime. If it is brought into completion at all, that completion occurs only in the afterlife' $(2010,161)$. Importantly for our discussion of imitating Christ, the process of sanctification is one in which the believer both behaves, and becomes more like Christ.

Although Stump does not describe it as such, this completion of sanctification occurs at the beatific vision which initiates the third stage of this transformation: the process of 'deification' (or 'glorification'). ${ }^{7}$ Through deification, human beings enter into full union with God which is made possible only after death in which, 'we shall be like him' (1 John 3:2). Deification is the completion of the restoration of imago dei.

We can now see how important the imitation of Christ is theologically. God's purpose is to bring humanity into union with him and to restore the imago dei. Union with God is only possible after death, when the agent shall 'be like him' (1 John 3:2) through the completion of her deification. If the believer's ultimate aim is to be fully like Christ and to be restored into the image of God, then the aim of the present spiritual life, is to engage in sanctification; the act of becoming like Christ. Sanctification, then, is the process of imitating Christ. And, as we have seen from the passages above, this has a distinctly moral element (the believer behaves more like Christ) and a metaphysical element (the believer will be more like Christ).

With the theological importance of imitation explained, I now go on to consider just what imitating Christ consists of.

\section{Imitating Christ: a problem}

So what might an account of imitating Christ consist of? And what conditions can be given for such an account?

In imitating a person, we might think, an agent attempts to replicate or copy some feature of another person's actions or behaviour. There are existing examples of this kind of imitation in the Christian tradition; when Paul instructs believers to '[b]e imitators of me, as I am of Christ.' (1 Corinthians 11:1), or in the popular Catholic devotional book, The Imitation of Mary, in which we are told, 'Happy the man who imitates our Lady, for in imitating her he imitates Jesus' (De Rouville (1980), 15), these are instances which an agent imitates important religious figures by attempting act in a way which is in keeping with what she knows about Mary, or Paul. This kind of imitation is not constrained to Scripture, either. For instance, one might be so humbled by reading the biography of Dietrich Bonhoeffer that she seeks to imitate Bonhoeffer in some way-by acting like him, speaking like him, and maybe even thinking like him. If imitation simply consists in an attempt to replicate some kind of behaviour of another person, then imitating Christ simply consists of attempting to perform the actions which Christ is reported to have performed. And this is precisely what the

\footnotetext{
${ }^{7}$ See David Efird and David Worsley's (2015) critical review of Stump's Wandering in Darkness for a more detailed discussion of this point.
} 
'WWJD?' movement tells us; by thinking about how Christ might respond to the situations we face, we have a helpful framework for Christian ethics as an imitation of Christ. ${ }^{8}$

The problem with this approach, however, is that imitating Christ is not equivalent to imitating Bonhoeffer or even Paul. Copying certain examples of behaviour from historical individuals might change our own thinking and behaviour in certain ways. However, if imitating Christ is essential for the redemption of human agents through the process of sanctification, and eventually, deification, then it will be important that our account of imitation captures the transformative nature of this process. It is not obvious that mere behaviour replication can do this. In becoming more Christ like, the aim is not a small scale change of the believer's behaviour and preferences, but, rather, a metaphysical change in which she both acts like and becomes like Christ. ${ }^{9}$ The sum total of what know about Christ, however, can be fitted into four very condensed biographical accounts. We know far more about Bertrand Russell, Dietrich Bonhoeffer and even Plato than we know about Christ. If the aim of the Christian spiritual life is to be more like Christ in every way, however, it is not obvious how Christ would respond in every scenario. It might be obvious that Christ would give to the poor if asked to but would Christ always tidy his room if his mother asked him to? Would Christ buy battery farmed eggs? It is not clear how asking 'WWJD?' can help us here. Whilst it may be of some help in allowing us to act more like Christ in some ways, it will be severely limited in helping us to be more like Christ in the deep, transformative manner which is required for our sanctification and deification.

For an account which captures what it means to imitate Christ, then, it will not be sufficient that the believer can do a good impression of Christ; imitation cannot be restricted to a small set of actions which the Christian believer is required to replicate. Rather, imitating Christ is a lifelong task which aims at the cognitive, moral and personal transformation of one's whole self. It is important not only that the believer's behaviour is Christ like, then, but also her desires, preferences and will must be transformed to be more like Christ's. ${ }^{10}$

It is possible to give a more plausible account of imitating Christ, I think, which gives a more detailed and focused account of what imitation is and what it aims at doing. In doing this, we can give a less problematic account of what imitating Christian is and how it is possible. In order to do this, it will be important to take note of certain features of the extensive psychological literature on imitation.

\section{Imitation and behaviour replication}

Before I go on to give an account of imitating Christ, it is important to first adopt a clearer definition of imitation, in order to see how well it fits the theology of imitating Christ. Thankfully, such a definition has already been proposed, revised and refined many times over

\footnotetext{
${ }^{8}$ A helpful discussion of the theology behind the 'WWJD' wristbands is given by A.K.M. Adam in 'Walk This Way. Repetition, Difference and the Imitation of Christ'

${ }^{9}$ Through the process of imitation, the Christian believer goes through what L.A. Paul describes as a 'transformative experience' $((2014), 1)$. That is, the imitation of Christ is an experience which is cognitively and personally transformative to such an extent that the agent cannot project forward to what it will be like to be fully like Christ.

${ }^{10}$ As well as the problem of how copying Christ's actions allows for transformation, there is also a practical problem with imitating Christ - that is, it is not obvious how to begin copying or replicating someone who is morally perfect. We need an account of imitation not only to be theologically coherent, but also to give us some practical guidance on how to engage in the process. Telling someone to do what Jesus would do is of little or no help, here.
} 
in the psychological literature on imitation and infant development. Although the aims of discussing imitation in Christian theology are vastly different from the aims of the discussion of imitation in cognitive psychology, the extensive psychological literature in this area can provide some important insights for the theology of imitation, or so I argue. Of particular importance for psychology, and something which can help focus our theology of imitation, is the distinction between behaviour replication and the replication of goal-oriented intentional actions. In order to imitate another person, or so Ellen Fridland and Richard Moore (2014) tell us, the replication of certain behaviour is not sufficient, but rather, it is also necessary that the imitator recognizes, and aims at reproducing, the particular goal-directed intentions of the person being imitated ((2014), 874). As I go on to argue, this difference is crucial for understanding what it means to be imitator of Christ. That is, merely replicating the reported behaviour of Christ will not allow for true imitation of Christ.

As Susan Hurley and Nick Chater note, 'imitation is a rare ability that is fundamentally linked to characteristically human forms of intelligence, in particular, to language, culture, and the ability to understand other minds' ((2005), 1). The ability to imitate or replicate certain behaviour occurs very early in human beings, it has been demonstrated that '[n] ewborn infants less than an hour old can...imitate facial gestures.' (Gallagher, ((2005), 70-2). This early skill of imitating another person has an important role to play in the development of language, social skills and even moral behaviour. ${ }^{11}$ Imitation occurs both at an intentional, goal orientated level in which the infant aims at copying certain behavioural traits, and also on a subconscious level.

So what does it mean to imitate another person? Straightforwardly, imitation is the copying of certain kinds of observed behaviour in other agents. However, whilst all imitation is a kind of behaviour replication, not all behaviour replication is imitative. Fridland and Moore, in their recent reworking of Michael Tomasello's (1996, 1999a, 1999b, \& Boesch, 1998 , \& Carpenter, 2005) work on imitation, distinguish between three kinds of behaviour replication: emulation, mimicry and imitation ((2014), 858). As Boesch and Tomasello describes it, emulation learning is 'the process whereby an individual observes and learns some dynamic affordances of the inanimate world as a result of the behaviour of other animals and then uses what it has learned to devise its own behavioural strategies' ((1998), 598). Thus, to take an example, in observing someone using the self-scan till at supermarket, Jill may emulate the behaviour of the individual in front of her since she sees that by scanning the barcode on the item, and then inserting cash into the relevant slots, she may purchase her shopping. She does not aim at reproducing the particular technique of scanning; she is concerned with the manipulation of the self-scan till in order to complete her transaction. As Fridland and Moore emphasise, emulation learning is concerned with 'the outcomes of others' activity, but not on the precise actions that they perform' ((2014), 858); the emulative learner takes the behaviour of others to best understand the object being manipulated, and to then use this understanding in achieving one's own goals. ${ }^{12}$ Crucially, emulation is not concerned with the intentions of the person being observed, but only on certain outcomes.

Another important kind of behaviour replication which is discussed in the literature, is the mimicry of behaviour. As Want \& Harris define it, 'mimicry is...the replication of a

\footnotetext{
${ }^{11}$ On the role of imitation in moral development, see Jesse J. Prinz, 'Imitation and Moral Development' in Hurley \& Charter, Vol 1., pp. 267-300.

${ }^{12}$ It is this process of emulation, according to Tomasello, which is the primary process by which non-human primates learn socially (1996).
} 
model's actions in the absence of any insight into why those actions are effective, or even what goal they serve' ((2002), 3). A parrot, for instance, mimics human speech without aiming at reproducing any intentions or goals of the communicator (Fridland and Moore (2014), 859). It is possible, in mimicking someone, to be entirely ignorant of the meaning or intention of the behaviour which is reproduced.

According to Fridland and Moore, although in both mimicry and emulation agents focus on some kind of behaviour replication, neither should be understood as instances as imitation. The reason for this, is that the individual who imitates is concerned both with the intention behind the action, as well as the replication of action. To see how emulation and mimicry differ from imitation more clearly, consider an example from a parallel discussion in the philosophy of artificial intelligence. As well as providing a pithy title for an article discussing the imitation of Christ, Alan Turing's (1950) 'imitation game', provides a helpful way of clarifying the difference between imitation and other kinds of behaviour replication. Turing's 'imitation game' is a test which aims at demonstrating that machines can think-an interrogator communicates with both a human subject and a digital computer and then attempts to correctly identify which is which ((1950), 433-4). If the two subjects were indistinguishable, Turing thought, we would have some evidence for artificial intelligence. Turing's game infers a level of sophisticated mental processing from a replication of human behaviour. However, as Donald Davidson argues, 'Turing's Test eliminates the possibility of telling whether a creature or machine thinks without determining what it thinks...the Test makes meaningful verbal responses the essential mark of thought' ((2004), 80-1). Or, as John Searle (1980) discusses in his famous discussion of the Chinese Room, a successful computerised imitator can copy the syntax of human speech whilst lacking the semantics required for us to know what the computer means. In order for us to ask whether a machine can think, Davidson argues, we must be able to tell whether the computer means something by what it says ((2004), 82). Whilst Turing's machine might be able to do a good job of deceiving an interrogator, determining the meaning behind certain syntax requires not just that we process a collection of data from a subject, but that we observe the connections between the speaker and the world ((2004), 83). In order for there to be meaningful interaction (and not merely mimicry), Davidson thinks, we need to interact with the subject in relation to the world and not just receive raw data.

This objection brings out a useful distinction between imitation and other forms behaviour replication such as mimicry and emulation. The lesson we can learn from Davidson's objection, is that not all behaviour replication is imitative. In fact, the behaviour replication of human behaviour by a machine is not a good test of intelligence, precisely because there is no real imitation in the imitation game - only mimicry. Or, at the very least, it shows us that it would be impossible to detect genuine imitation by using such a technique.

So what, more precisely, distinguishes imitation from other forms of behaviour replication? Although there is a wide range of views on what exactly imitation is in the psychological literature, it seems to be uncontentious that for psychologists, imitation is more than just replication of behaviour. As Fridland and Moore go on go on to define it,

Imitation is the reproduction of an observed behavior where the agent imitating (1) recognizes the behavior of the demonstrator as goal-directed and (2) has some particular interest in or concern for replicating the precise technique performed by the author of the observed action. (2014, 874; emphasis in the original) 
The first condition helps us to see the importance of the agent's intention in imitating hercontrary to mimicry, when the agent imitates someone, she is concerned with the intention of the behaviour. For the parrot, it makes little difference why the person observed utters the words, 'Top of the morning!', nor is the machine which is programmed to ask 'How are you today?' concerned with emulating the intention of social interaction which the human who programmed it uses such an utterance for. To see that this is true, we only need note that for the computer or the parrot who mimic human behaviour, the replication of meaningless gibberish could be considered just as successful an act of mimicry as the above examples. Although there is disagreement concerning whether the agent must be aware of the intention behind the behaviour, or merely aware that the behaviour is intentional, at the very least, the minimal condition suggested above is necessary for imitation. Secondly, whereas emulation is 'outcome-centric', according to Fridland and Moore, imitation is 'technique-centric' ((2014), 869). The emulator seeks to get at the same results or ends as the agent being observed, whereas in imitation

observers should intend not just to reproduce the outcomes of others' intentional actions, but, additionally, to match precisely the actions that they produce in pursuit of these goals - in a manner that indicates that this careful matching of the behavior is itself a goal of the imitating subject (and end-in-itself)'. (Fridland and Moore, ((2014), 868)

Fridland and Moore's emphasis on the technique of the action, rather than the goal, is an important distinction which helps to distinguish the kind of behaviour replication which human infants perform from those of non-human primates, which are described and emulative and no imitative. As Tomasello writes, 'human children are much more focused on the actual actions of the demonstrator, whereas chimpanzees are much more focused on the outcome of her actions' ((2009), 217). To put it succinctly, then, imitation is a replication of certain observed behaviour in which the agent is concerned both with the intention, as well as the specifics of the observed behaviour.

We should note here that the definition of imitation given by Fridland and Moore intends to capture the minimum requirements for imitative behaviour replication, and that this minimum requirement will not be sufficient for imitation in some important cases. Most notably, for instance, it will not account for the kind of imitation which plays a role in infant cognitive development in its fullest sense. It is important for infant development not only that actions are experienced as goal-orientated, but that the goal-orientation of these actions is in some sense transparent to the infant. The transparency of intentions in cognitive development comes in stages, as Tomasello et al. (2005) note, although intention sharing is essential for cognitive development, prior to gaining the ability to do this, children are able the distinguish between animate and inanimate actions without being able to interpret the content of this in a complex way. So, Fridland and Moore's minimal kind of imitation will occur at the early stages of infant development, but as a child's cognitive capacities get more sophisticated, so too will the kind of imitation.

It is important then that we consider not only the minimal kind of imitation, but also the kind of imitation which occurs in childhood development. If imitation of Christ is as significant and transformative as described previously, then the minimal kind of imitation will not fit our theology of imitating Christ. I will return to this point shortly. Before doing so, it is important to note that the psychological literature on imitation has drawn extensively on recent findings in neuroscience which, as Hurley and Chater describe it, point towards a 
'direct link between perception and action' ((2005), 3). Of particular importance for the work on imitation is the discussion of the 'mirror-neuron system'-a set of neurons in the brain which appear to replicate or mirror observed actions in others, making possible a kind of mind-reading in which we perceive the intentions and emotional states of other persons.

In the early 1990s, Italian neuroscientists discovered that in monkeys, and then as later discovered, in humans, a set of neurons (which have come to be known as the "mirror neuron system') activated both during the execution of certain 'purposeful, goal-related hand actions' (Galese, 2003, 35) and when observing similar hand actions performed by another individual. This discovery shed light on our understanding of how primates interact, and more specifically, how they respond to the actions of others. According to Rizzolatti and Sinigaglia, the mirror system allows humans and non-human primates to 'catch in a flash' the intentions behind certain actions when they are performed by others ((2005), 114; emphasis in the original). And thus, they go on argue, 'it is possible to decipher the meaning of the "motor events" observed, i.e. to understand them in terms of goal-centred movements' ((2005), 125; emphasis in the original).

In human beings, it has been argued, the mirror-neuron system 'can accomplish a wider range of tasks than that observed in the monkey' ((2005), 124). The mirror neuron system does not just allow for understanding the intentions of certain goal orientated actions, but has a role to play in our emotional cognition of others as well. Christian Keysers and Valeria Gazzola, for instance, note that the mirror neuron system plays a role in our empathy towards other people; when an individual sees someone in pain, their brain responds by mirroring the pain and the same areas of the brain are activating as occur when we are in pain ourselves ((2009), 17-19) Furthermore, this can be extended to our imitation of the emotional states of others, or so Keysers and Gazzola maintain. When experiencing certain emotional states in other individuals, such as pleasure, disgust or indifference, for example, the human brain mirrors the experience and even produces similar facial expressions to those being observed. It has been demonstrated that the replication of facial expressions and emotional states in others is accompanied by the activation of the mirror-neuron system.

The importance of the mirror-neuron system for our current discussion is twofold. First, the direct perception of others' intentions, emotions and mental states allows for a complex kind of imitation which far surpasses the minimal requirements of Fridland and Moore's earlier discussion. The ability to 'mind-read' as it is often described, then forms the basis of many recent discussions of infant development in a wide range of areas - observing the actions and intentions of others, particularly care givers, parents and guardians, and then replicating these actions, is the primary way that children learn complex languages, social skills, and moral values.

Secondly, the discussion of mirror-neurons also points to another interesting feature of the literature on imitation, namely, that imitation is not only an intentional, purposive act of replicating observed behaviour, but also, a behaviour that happens at a subconscious level by the mirroring of observed behaviour in others. This points us to two different ways of thinking about imitation - both at the neural, subconscious level and at the intentional level. This mirrors a discussion in the philosophy of empathy, which is a closely connected area of philosophy and cognitive psychology. Alvin Goldman has argued that there are two distinct kinds of or 'routes to' empathy; 'the mirroring route and the reconstructive route' ((2011), 44). ${ }^{13}$ Empathy via the mirroring route is the kind of experience discussed above, whereby

${ }^{13}$ Karsten Steuber (2006) makes a similar distinction between 'basic' and 're-enactive' empathy ((2006), 131). 
the mirror-neuron system replicates or copies someone's emotions or mental states in an immediate, automatic and sometimes subconscious, way. Through this experience of mindreading, we literally feel someone else's pain. This is not the only kind of empathy, however. Reconstructive empathy, as Goldman describes it, occurs when we try and put ourselves in someone else shoes, by reflecting on their position in a process which requires effort, and intention $((2011,36)$. Although, as Goldman admits, the mirror-neuron system may play a part in this second route to empathy, this does not undercut the distinction, he thinks (2011, 44). The reason for this, Goldman argues, is that the main difference between mirroring and reconstructive empathy is that the first is an automatic process, and the second is an effortful process requiring imagination and thought $((2011), 44)$. No doubt the same can be said for our understanding of imitation; for whilst the brain subconsciously imitates others in an automatic and immediate manner, it is also possible to engage in intentional, effortful imitation of another. Both the mirroring and the reconstructive kinds of imitation will be important for infant development, and, indeed, I will argue, for our imitation of Christ.

\section{Imitation and Christ: a dilemma}

In the previous discussion, I noted that imitating Christ played an important transformative role which distinguished it from other more basic kinds of imitation, such as the imitation of Paul, Mary or Bonhoeffer. What should now be clear, is why this is the case, and why it is difficult for this kind of replication to play the transformative role it needs to. Imitating Christ by simply copying some feature of his behaviour, is more similar to what Fridland and Moore describe as a kind of emulation or mimicry. That is, when encouraged to behave as Christ behaves, it looks like the best we can hope for is either to copy some behaviour which Christ is reported to have performed — such as talking to lepers and outcasts, or sharing bread and wine with our friends, or to emulate what we take the intentions of Christ to be, in order to achieve our own goals and ends. That is, we might learn from Christ, in being compassionate towards the woman at well (John 4), that when faced with social outcasts, we should talk to them as equals and be respectful.

However, imitation, as we have seen, at the very minimal level, is the replication of some observed intentional behaviour. At the level required for moral and cognitive development, imitation involves a kind of mind-reading in which the agent perceives the intentions of another's behaviour and then replicates this behaviour. Further, we have seen that there is an important distinction to be made between low-level mirroring which occurs subconsciously and automatically, and high-level, intentional replication of another's action. Both kinds of imitation are vital for the kind of transformative development that we are concerned with. However, whilst reading about, and then copying, the behaviour or characteristics of some historical figure might have some impact on our own behaviour and attitudes, it certainly will not allow for imitation in the full-blown sense. How can we observe the behaviour and intentions of a person who existed more than two thousand years ago?

The problem, then, is this: if imitating Christ, to use the full technical sense of the word 'imitation', requires observation of Christ's intentions and behaviour, then this does not appear to be possible. The access we have to Christ is in a historical record of actions Christ is reported to have performed. If imitating Christ is not used in the full technical sense, and requires only a kind of copying of what we know about Christ, although this is possible, it is not clear that this kind of imitation can allow for the deep, personal and cognitive transformation that it needs to. So we either have to state that imitating Christ (in the transformational sense) is not possible unless we actually meet Christ and observe his actions, 
or we have to weaken our theological understanding of the role of imitation in our transformation and sanctification. It is clear that neither option if preferable.

In the remainder of this article, I attempt to resolve this dilemma. In what follows, I suggest that imitation of Christ is the full, technical sense, is indeed possible. In particular, if the recent work analysing the nature of Christian religious experience by Eleonore Stump (2012) and Adam Green (2009, with Quan (2012)) is correct, then we have a model which can explain how imitating Christ is possible through an experience of his presence.

\section{Joint-attention and imitation}

The underlying assumption which motivated the dilemma facing our understanding of the imitation of Christ was that Christ is a historical person who we can read about, and learn about, but not a living person who we can engage with and experience. It is clear, though, that this assumption is neither in keeping with Christian tradition and theology, nor Christian practice and belief. If this is the case, and Christ is a living person who we can engage with and experience, then perhaps, it might be argued, the technical notion of imitation can be applied to our imitation of Christ.

First, we should note that Christian theology typically puts prominence on the fact that relationship with Christ is not relationship with a historical figure, but with a living person; as John the Evangelist states, 'our fellowship is with the Father and with his Son Jesus Christ.' (1 John 1:3), or, according to Christ himself: 'I am with you always, to the close of the age' (Matthew 28:20). As prophesied in Isaiah (7:14) and then fulfilled at his birth (Matthew 1:23), Christ is called 'Immanuel' which translates as 'God with us'. The Incarnation brings with it a new intimacy with God which 'removes the veil' of separation between humanity and God (2 Corinthians 3:14). The withness of Christ does not refer merely to some historical event, but Christ as Immanuel has present significance for the contemporary Christian believer.

Secondly, this emphasis on Christ as a living person is reflected in the discussion of spiritual practice. Anthony Bloom, for instance writes that 'prayer is an encounter and a relationship' $(1970,2)$. The importance of Christ as a living person is also reflected in reports of religious experience. Consider an example from Bloom's conversion account, for example:

While I was reading the beginning of St Mark's Gospel, before I reached the third chapter, I suddenly became aware that on the other side of the desk there was a presence. And the certainty was so strong that it was Christ standing there that it has never left me. This was the real turning point. Because Christ was alive and I had been in his presence I could say with certainty that what the Gospel said about the crucifixion of the prophet of Galilee was true. (1970, xii)

Although Bloom's report, and others like it, describe experiences of the person of Christ, it is not obvious yet how this solves the dilemma we considered. In order to see how this is possible, we need first to understand better the nature of religious experience and experiences of Christ's presence with and to his followers.

According to Adam Green, religious experiences can be understood as instances of joint-attention (or shared-attention) with Christ. ${ }^{14}$ Importantly for us, Green's model of religious experience also happens to be the way that psychologists account for the kind of

\footnotetext{
${ }^{14}$ Note that Green talks about shared-attention with God more broadly rather than only shared-attention with Christ.
} 
engagement individuals need to have with one another in order to mind-read, and thus, to imitate. ${ }^{15}$ To describe it simply, joint-attention is a form of social engagement in which we are aware that another person is 'in engagement with an object or potential object as a process over time' (Reddy (2011), 137). As Axel Seemen notes in his volume on joint-attention, although 'the discussion of joint attention is anything but unified' $((2011), 1)$, there is a common position which all discussions of joint-attention share. Namely 'that an adequate understanding of the life of the mind has to pay particular attention to its social dimension' ((2011), 2), and move from a 'solipsistic conception of mind...toward a view of mental phenomena as inherently social' ((2011), 2). Crucially for my argument, then, joint-attention experiences are an important part of social engagement in infant development and the process of imitation.

An infant's awareness and engagement with other persons develops over time, and begins with a kind of dyadic-joint-attention, that is, attention which requires only awareness of another person through a kind of mutual gazing. This basic kind of attention sharing is possible very early on in infants (from zero to two months, according to Vasudevi Reddy ((2011), 145)). The ability to jointly-attend then develops into a kind of triadic joint-attention, at around four to five months, that is, joint-attention in which an infant gains the ability to focus on some independent object whilst still remaining aware of the other person (Reddy (2005), 85-7). To clarify with an example: when a child looks her mother in the eye, then points towards an object, and then looks back to the eyes of the mother, if the mother follows the direction of her child's gaze, then they had a dyadic joint-attention to begin with, followed by a triadic joint-attention focusing on the object. ${ }^{16}$ This ability to follow the gaze of others and mutually focus on objects in a kind of triadic attention develops later, at around nine to fourteen months, into ability of engaging in the process of 'imitating actions on objects' ((2011), 145).

As developmental psychopathologist R. Peter Hobson, notes, joint-attention experiences are essential to the development of an infant's ability for intersubjective engagement and mind-reading ((2004), 85-109). Hobson cites an experiment conducted in which infants were shown a monitor with a real time feed of their mother and others with a delayed feed of their mother. The infants who engaged with the real time feed responded as if the mother were present in the room, whereas the infants responding to the delayed feed showed signs of distress and looked away ((2004) 38-9). What Hobson takes from this study is that there is a difference between merely responding to certain emotions as they are expressed facially and responding to emotions when we engage in joint-attention with the other person. Or in other words, dyadic and triadic joint-attention experiences are vital to our intersubjective experiences of others and are required for imitation.

Drawing from this discussion of joint-attention in the psychological literature, Green then argues that religious experiences are best understood as instances of joint-attention with God, rather than, say, experiences in which the believer perceives God in some way. ${ }^{17}$ Often, when we come to describe religious experiences, Green notes, we overlook the fact that God is a person. If God is an inherently personal being who is aware of all human beings and desires to be in communion with them, he claims, we should expect that his interactions with

\footnotetext{
${ }^{15}$ The discussion of joint-attention in the psychological literature is as vast as that on imitation, and I will not have space for a detailed discussion. For an excellent volume which discusses the importance of joint-attention, see, Axel Seeman's (ed.) Joint Attention.

${ }^{16}$ This is similar to an example which Green considers ((2009), 460).

${ }^{17}$ Such as Alston's (1993) account in Perceiving God, for example.
} 
us would be in some way personal rather than merely perceptual ((2009), 461-2). Green proposes a joint-attention model of mystical experience as follows:

One is engaged in dyadic shared attention with God iff one is aware of God as exhibiting some mental state which is directed towards oneself and the mental state which God exhibits involves an awareness of the co-operative nature of the present attention. This co-operation will be invested with an interactive pattern of affect since to experience God is to experience both the source of all goodness and to experience someone who wants to have them most intimate of relationships with one. ((2009), 462)

According to Green, this model of religious experience makes sense both of the personal nature of God and of the reports of experiences we find in testimony such as Bloom's. The joint-attention model offers a way of understanding religious experience which allows for a description of how actions are perceived as well as emotions and intentions. It also means that God can manipulate the media by which we perceive the world (light, sound etc.) to reveal his emotions and actions towards us. According to Green's model, the individual who experiences God through joint-attention does not have to perform an inference to establish that she is experiencing God, but there is a kind of intersubjective relation that occurs between God and her. The individual experiences something of God's emotions or intentions whether that be God's loving, or God's forgiving or God's imparting mercy. To use an example, when reading Scripture we may become aware that God is present with us (dyadic joint-attention) and then, after reading some words in which God speaks, experience him speak directly to us and have an experience in which he is drawing attention to the pride in our heart (triadic joint-attention), for instance. ${ }^{18}$

We are now in a position to consider how experience of Christ relates to imitating Christ. The kind of experience which will be relevant for our imitation of Christ will be sharing attention with Christ. Many religious experiences are already understood as experiences of Christ, rather than just as experiences of God. Sharing attention with Christ, I think, is a particular subset of sharing attention with God. If Green's analysis is correct, then experience of Christ is an example of joint-attention in which Christ's emotions and intentions are revealed to us in an immediate way. This can give us an important basis for understanding how imitating Christ is possible in the full technical sense we previously discussed. However, before spelling this out in more detail, it is important to consider the fact that, according to the Christian tradition, Christ is not only present to us and with us, but the Holy Spirit is also present in us.

\section{Imitation and indwelling}

As I described it earlier, Paul's description of imitation and the restoration of the imago dei from 2 Corinthians 3, is a process in which the believer has direct access to God through Christ, made possible by the Holy Spirit. An important aspect of imitation which I have yet to consider, then, is the role of the Holy Spirit. According to Christian doctrine, one of the ways Christ is present to us in our ordinary lives, is through the indwelling of the Holy Spirit. How should we best understand this doctrine? A helpful way of thinking about what it means to be

${ }^{18}$ Green and Quan, 'More than Shared Propositions: Shared Attention and the Religious Text' Green and Quan apply the joint-attention model to our understanding of God's living presence through Scripture. 
present in something can be found in another discussion of Christian doctrine- the presence of Christ in the Eucharistic elements. When we say that Christ is present in the Eucharistic elements, following Ross Inman's (forthcoming) account of presence, we could understand this in terms of fundamental location, that is, we could say that Christ's body is located in a particular space at a particular time. Or, alternatively, we could understand this as a kind of derivative presence, in which case Christ's body is present in virtue of standing in relation to a person who is present in a particular space at a particular time (Inman (forthcoming), 3). That is, the Eucharist elements provide an occasion for and mode of experiencing Christ's presence. ${ }^{19}$ Similarly, then, when we say that the indwelling of the Holy Spirit makes it possible to experience Christ's presence, we could understand this as a claim about Christ's derivative location in a person. Described as such, the indwelling of the Holy Spirit acts as an occasion for and mode of experiencing Christ's presence. A helpful way of describing the Holy Spirit's indwelling as an instance of derivative presence can be seen by looking at Stump's discussion of this doctrine.

As Stump describes it, when an individual Paula, comes to faith, 'the indwelling of the Holy Spirit puts the mind of God within Paula's psyche, in some sense' ((2012), 80). As Stump notes, the Holy Spirit's indwelling cannot be understood merely as God having maximal knowledge about Paula, but 'it is also possible for God to communicate in a direct and unmediated way with the mind of that person' ((2012), 80). Stump then goes on to propose a model of indwelling which she draws from the psychological literature on jointattention, mindreading and mirror neurons. As Stump describes it, a mutually loving union between two persons is one in which there is 'a particularly intimate kind of mind-reading accompanied by shared attention between persons' $((2012), 80)$.

However, even this intimate kind of relation between two persons in love will be not sufficient to explain the intimacy of the Holy Spirit's indwelling, Stump argues. Moving beyond an account of mindreading, Stump then discusses the kind of mind-sharing that would be needed for indwelling to be possible. She notes that in cases of neural dysfunction or injury, 'a patient can suffer the delusion that some part of his body is not his own' ((2012), 83). Building on this possibility, of experiencing other's mental states as one's own, Stump argues that

[b]ecause of the systems of the human brain for recognizing some mental states as one's own, it is also possible for a person Jerome to have a sense of the mind operative in him as not his own but someone else's. In a case of this sort, the intersubjectivity of mental states enabled by the mirror neuron system and evident in mind-reading transforms from a mere psychological sharing to something that is ontological. What is in Jerome's mind is not just another person's thought or affect, but in fact that other person's mind. "Indwelling" is not a bad word for this kind of relationship between minds. ((2012), 83)

Although at face value, Stump's proposal sounds a little far-fetched, and is certainly beyond the scope of current psychological study of intersubjective relations, it is a helpful way of making sense of how a person could indwell in another. Stump's proposal also makes good

${ }^{19}$ Unfortunately, there is not space here for a detailed development of this account of the Eucharist. However, it has potential to solve many of the problems which existing accounts of Christ's presence in the Eucharist raise. For more details on this interpretation of the Eucharist, see (Cockayne et al., Ms.) 
sense of the theology of indwelling as it describes God as actually present in a human being, rather than merely present with or present to. It also gives a helpful way thinking about the description of derivative presence I described earlier. And although Stump doesn't focus exclusively on Christ's presence made possible through the indwelling of the Spirit, as Christ tells us in the Gospel according to John, one of the roles of the Holy Spirit is to reveal Christ to the individual (John 16:14-16). Whilst there is not space to fill this out in detail here, if our imitation of Christ requires not only action replication, but also some understanding of intention and a kind of mind-to-mind connection, then the permanent indwelling of the Holy Spirit, understood as an occasion for and mode of experiencing Christ's presence will provide a helpful way of understanding how imitation is possible.

\section{Imitating Christ: a joint-attention account}

If Green's and Stump's accounts of presence and experience as instances of joint-attention and mind-to-mind engagement with God are correct, then it appears that there is a way of resolving the prior dilemma. That is, if we can engage with Christ as a person and shareattention with him in both a dyadic and triadic way, then plausibly, we can also imitate Christ in a way that is spiritually developmental and radically transformational.

In contrast to the WWJD model, then, imitation does not begin with an attempt to work out what Christ has done and might do, but it should begin with an experience of Christ's presence. As we have seen with Goldman's distinction between higher-level and lower-level empathy, there are different kinds of imitation-imitation occurs a subconscious level when we share attention with a person, but we must also work at the process of imitation ourselves. Imitation, as a form of sanctification, is a co-operative and purposive venture, not a passive change. And so, imitation, whilst beginning with an experience of Christ's presence, will go on to involve intentional and disciplined action on behalf of the imitator, but this will only be made possible, I maintain, if imitation begins with a direct experience of Christ, made possible the by the indwelling of the Holy Spirit.

Thus, there is no dilemma for our understanding of imitation, since imitation in the full transformative sense is only possible through joint-attention and personal engagement, and since such an experience is possible of Christ, then we can affirm both the theological importance of radical transformation, as well as defending an account of imitation which is both practical and plausible.

It may be the case, however, that this account is too restrictive in allowing imitation only to those who have vivid experiences of Christ. This objection should not be too troubling if we recall our earlier discussion. Imitation is a process which will not be complete in this life. Recall Paul's claim that: "we all, with unveiled face, beholding the glory of the Lord, are being changed into his likeness from one degree of glory to another' (2 Corinthians $3: 18$ ). Imitation is about being changed into his likeness; the verb 'being' here implies that coming into Christ's likeness is not an immediate thing. Indeed, it is not a change which can be fully achieved in this life, as he maintains later, "now we see in a mirror dimly, but then face to face. Now I know in part; then I shall understand fully, even as I have been fully understood.' (1 Corinthians 13:12). And so imitation of Christ is something we aim to cultivate but never expect to complete.

Just as an infant's development requires stages of personal presence, according to Reedy $((2011,145)$, we should also expect the experience of Christ's presence comes in stages. From a minimal kind of presence, such as the one described by Tracey Emin in her Liverpool Cathedral instillation, 'I felt you, and knew that you loved me', to the vivid experiences of William James, who claims that 'I could not any more have doubted that He 
was there than that I was. Indeed, I felt myself to be, if possible, the less real of the two' (1994, 66-67). If our prior account of sanctification was correct, then this is to be expected; sanctification is a cooperative and ongoing process which results in becoming more like Christ through the development of our spiritual attention-sharing abilities. As Brother Lawrence describes in The Practice of the Presence of God, the experience of God's presence requires practice and discipline. The 'habitual sense of God's presence' $(2009,17$; emphasis in the original) Brother Lawrence reportedly experienced was not an immediate experience, but one which required years of worship and confession. Indeed, the other kinds of behaviour replication may be useful here - in emulating or mimicking Christ's actions as they are recorded in Scripture, we may open ourselves up to the possibility of genuine imitation and attempt to cultivate an awareness of the presence of Christ.

This response helps to draw out what is crucial to our understanding of imitating Christ; the aim of the Christian spiritual life should be a kind of cultivation of the awareness of Christ's presence. Seeking after the presence of Christ is crucial to understanding how the individual imitates Him - if we want to imitate Christ we must aim to spend time with Christ and develop an awareness of his presence. This brings a new significance to the spiritual practises which enable us to experience Christ's presence and help us to become more aware of this through our practice. That may be by experiencing Christ through Scripture, which, in the Christian tradition is of vital importance for hearing God's words and experiencing his presence today. It may be through mystical experiences such as the ones described above, or through simple meditation and prayer. Interestingly, this also gives an added dimension to the discussion of what it means to experience Christ in the Eucharist. ${ }^{20}$ If the model of imitation I propose in this paper is correct, then there are countless applications of this to our understanding of the Christian spiritual life.

\section{Conclusion}

The imitation of Christ has an important role to play in our understanding of the Christian spiritual life and the restoration of the imago dei through the process of justification, sanctification of deification. What I have attempted to offer, in appealing to the psychology of imitation, is an account of just what this imitation consists of. The psychology of imitation sheds light on our imitation of Christ and the importance of cultivating an awareness of the presence of Christ in the Christian spiritual life. If imitating Christ begins by experiencing the presence of Christ along with his actions, emotions and intentions, then this model gives us an insight into some existing problems in the philosophy of spirituality and has potential to be applied, I think, to a wide range of topics in this area. ${ }^{21}$

\footnotetext{
${ }^{20}$ Although there is a small amount of work done on Eucharist as imitation (see Laurence, 'The Eucharist as Imitation of Christ'), there is considerable potential here, I think, for a philosophical analysis of the Eucharist as joint-attention with, and, imitation of, Christ. ${ }^{21}$ I would like to thank David Efird for his detailed feedback and advice on the multiple drafts of this article which have existed. I would also like to thank David Worsley, Chris Jay, Adam Green, as well as the members of the St. Benedict Society for Philosophical Theology and Philosophy of Religion at the University of York for their helpful feedback on earlier drafts of this article.
} 


\section{REFERENCES}

ADAM, A.K.M 2001: 'Walk This Way. Repetition, Difference and the Imitation of Christ' Interpretation, 55: (1) 19-30

ALSTON, William 1993: Perceiving God: The Epistemology of Religious Experience, Cornell University Press, Reprint Edition

BERNARD of Clairvaux: Sancti Bernardi opera, ed. Jean Leclercq, Charles H. Talbot, and Henri-Marie Rochais (Rome 1957-77) Serm. 2 in die Pentecostes, 5, p. 168

BLOOM, Anthony, 1970: Beginning to Pray (New York: Paulist Press, 1970)

BOESCH, C., \& TOMASELLO, M., 1998: 'Chimpanzee and human cultures' Current Anthropology, 39(5), 591-614

COCKAYNE, Joshua, EFIRD, David, HAYNES, Gordon, LUDWIGS, August, MOLTO, Daniel, TAMBURRO, Richard, WARMAN, Jack, Ms. 'Experiencing the real presence of Christ in the Eucharist'

CONSTABLE, GILES, 1995: Three Studies in Medieval Religious and Social Thought, (Cambridge: Cambridge University Press)

DAVIDSON, Donald, 2004: Problems of Rationality, Oxford: Oxford University Press

DE ROUVILLE, Alexander, 1980: The Imitation of Mary, Revised and Edited by Matthew J. O’Connell, Catholic Book Publishing Corp. New Jersey

EFIRD, David \& GUSTAFSSON, Daniel, 2015: 'Experiencing Christian art' Religious Studies, 51 (3): 431-439

EFIRD, David \& WORSLEY, David, 2015: 'Critical Review of Eleonore Stump's Wandering in Darkness: Narrative and Problem of Suffering' Philosophical Quarterly, 65 (260) 547-558

FRIDLAND, Ellen \& MOORE, Richard, 2014: 'Imitation Reconsidered' Philosophical Psychology (6): 856-880

GALLAGHER, Shaun, 2005: How the Body Shapes the Mind, Oxford: Oxford University Press

GALLESE, Vittorio: 2005: "'Being Like me": Self-Other Identity, Mirror Neurons, and Empathy' from Imitation: From Neuroscience to Social Science, ed. Susan Hurley and Nick Chater (Cambridge, Mass, MIT Press, 2005)

2003: 'The Roots of Empathy: The Shared Manifold Hypothesis and the Neural Basis of Intersubjectivity' Psychopathology, 36: 171-180 
2001: "The "Shared Manifold" Hypothesis: From Mirror Neurons to Empathy, 'Journal of Consciousness Studies, 8: 33-50

2000: 'The inner sense of action. Agency and motor representations' Journal of Consciousness Studies, 7, 10, pp. 23-40

GOLDMAN, Alvin 2011: 'Two Routes to Empathy' in Amy Coplan \& Peter Goldie (eds.) Empathy and Psychological Perspectives (Oxford: Oxford University Press)

GREEN, Adam, 2009: 'Reading the mind of God (without Hebrew lessons): Alston, shared attention, and mystical experience' Religious Studies, Vol. 45. Issue 4, 2009 pp. 455-470

GREEN, Adam and QUAN, Keith A 2012: 'More than Shared Propositions: Shared Attention and the Religious Text' Faith and Philosophy, Vol. 29, issue 4, pp. 416-430

HOBSON, R. Peter 2004: The Cradle of Thought: Exploring the Origins of Thinking, Oxford: Oxford University Press

2005: 'What puts the jointness into joint attention?', in Naomi Elian, Christoph Hoerl, Teresa McCormack, \& Johannes Roessler (eds) Joint Attention: Communication and Other Minds, 85-109

HURLEY, Susan \& CHARTER, Nick (eds.) 2005a Perspectives on Imitation: From Neuroscience to Social Science, Vol. 1, MIT Press

2005b. Perspectives on Imitation: From Neuroscience to Social Science, Vol. 2, MIT Press

INMAN, Ross, forthcoming: 'Omnipresence and the Location of the Immaterial' in Jonathan Kvanvig (ed.) Oxford Studies in the Philosophy of Religion Volume 7 (Oxford: Oxford University Press)

JAMES, William 1902/1994: The Varieties of Religious Experience: A Study in Human Nature. New York: The Modern Library

KEYSERS, Christian, GAZZOLA, Valeria: 2009 'Unifying Social Cognition' in Mirror Neuron Systems: The Role of Mirroring Processes in Social Cognition, Edited by Jaime A. Pineda, Humana Press 2009, pp. 3-38

KIERKEGAARD, Søren: Practice in Christianity, Kierkegaard's Writings, XX, Translated by Howard V. Hong and Edna H. Hong. Princeton: Princeton University Press, 1991

LAURANCE, JD 1986 'The Eucharist as Imitation of Christ' Theological Studies, 198647 pp. 286-296

LAWRENCE, Brother, 2005: The Practice of the Presence of God, Dover Publications

PAUL, L.A, 2014: Transformative Experience, (Oxford: Oxford University Press) 
PRINZ, Jesse, 2005: 'Imitation and Moral Development' in Hurley, Susan \& Charter, Nick (eds.) 2005 Perspectives on Imitation: From Neuroscience to Social Science, Vol. 1, pp. 267300

REDDY, Vasudevi, 2011: 'A Gaze that Grips with me' in Joint Attention, edited by Axel Seemann, 2011, (Cambridge, Mass: MIT Press)

2005: 'before the "third element": understanding attention to self', in Naomi Elian, Christoph Hoerl, Teresa McCormack, \& Johannes Roessler (eds) Joint Attention: Communication and Other Minds, 85-109

RICCIARDI, E., BONINO, D., SANI, L., VECCHI, T., GUAZZELLI, M., HAXBY, J.V., 2009 'Do we really need vision? How Blind People "See" the Actions of Others' The Journal of Neuroscience, 2009, 29 (31) pp. 9719-9724

SEARLE, John, 1980: ‘Minds, Brains and Programs' Behavioural and Brain Sciences, 3: 417-57

SEEMAN, Axel (ed.), 2011: Joint Attention (Cambridge, Mass: MIT Press)

STEUBER, Karsten, 2006: Rediscovering empathy: Agency, folk psychology, and the human sciences (Cambridge, Mass: MIT Press)

STUMP, Eleonore: 2013 'Omnipresence, Indwelling and the Second-Personal', European Journal for Philosophy of Religion, 5/4 (Winter 2013) pp. 63-87

$$
\begin{aligned}
& 2010 \text { Wandering in Darkness (Oxford: Oxford University Press) } \\
& 2003 \text { Aquinas (London/New York: Routledge }
\end{aligned}
$$

TAULER, Johannes 1910: The Following of Christ, translated by J. R Morett, C. Fischer Unwin, London 1910

THOMAS, à Kempis, 1952: The Imitation of Christ, Translated by Leo Sherley-Price (Harmondsworth: Penguin Books)

TOMASELLO, M., 1996: ‘Do apes ape?' In C. M. Heyes \& B. G. Galef (Eds.), Social learning in animals: The roots of culture (pp. 319-346). (San Diego, CA: Academic Press.) 1999a: 'Emulation learning and cultural learning' Behavioral and Brain Sciences, 21 (5), 703-704.

1999b: The cultural origins of human cognition. (Cambridge, MA: Harvard University Press)

2009. 'The question of chimpanzee culture, plus postscript (chimpanzee culture, 2009)' In K. Laland \& B. Galef (Eds.), The question of animal culture (pp. 198-221). (Cambridge, MA: Harvard University Press) 
TOMASELLO, M., \& CARPENTER, M., 2005: 'Imitation reading and imitative learning.' In S. Hurley \& N. Chater (Eds.), Perspectives on imitation: From neuroscience to social science. Imitation, human development, and culture (Vol. 2, pp. 133-148). (Cambridge, MA: MIT Press)

TURING, Alan, 1950: 'Computing Machinery and Intelligence', Mind, Vol. LIX, No. 236, pp. 433-60

WANT, S., \& HARRIS, P., 2002: 'How do children ape? Applying concepts from the study of non-human primates to the developmental study of 'imitation in children'. Developmental Science, 5(1), 1-41.

\section{NOTES}

